\title{
Effect of multiple antibiotic treatments on a paralytic shellfish toxin-producing culture of the dinoflagellate Alexandrium minutum
}

\author{
Elizabeth W. Maas ${ }^{1}$, Rebecca M. Latter ${ }^{1}$, Jürgen Thiele ${ }^{1}$, Anya M. Waite $^{2,3}$, \\ Heather J. L. Brooks ${ }^{1, *}$ \\ ${ }^{1}$ University of Otago, Department of Microbiology and Immunology, PO Box 56, Dunedin 9054, New Zealand \\ ${ }^{2}$ Victoria University of Wellington, School of Biological Sciences, PO Box 600, Wellington 6012, New Zealand \\ ${ }^{3}$ Present address: School of Environmental Systems Engineering, University of Western Australia, 35 Stirling Highway, \\ Crawley 6009, Western Australia, Australia
}

\begin{abstract}
Alexandrium minutum is one of several dinoflagellate species capable of producing paralytic shellfish toxins. Previous work suggests that toxin levels are influenced by a number of parameters, including dinoflagellate-associated bacteria. In the present study, a toxin-producing culture of A. minutum isolated from Anakoha Bay in the Marlborough Sounds of New Zealand was subjected to an antibiotic treatment regimen designed to eliminate the associated bacteria. Antibiotics used included penicillin, streptomycin, kanamycin and tetracycline (Treatment 1); ciprofloxacin and gentamicin (Treatment 2); and penicillin, streptomycin and ciprofloxacin (Treatment 3). Enzyme immunoassay showed that saxitoxin levels in the A. minutum culture fell significantly following the first round of antibiotic treatment, and this coincided with a large reduction in the associated copiotrophic bacterial population. HPLC data indicated that there was also a reduction in gonyautoxins $\left(\mathrm{GTX}_{1-3}\right)$. The oligotrophic population was more difficult to eliminate and required 2 additional rounds of antibiotic treatment, but saxitoxin levels did not change any further. Scanning laser confocal microscopy following acridine orange staining was used to observe intracellular bacteria-like particles, which were considerably reduced by the end of the treatments, probably due to the inclusion of antibiotics that penetrate eukaryotic cells. Algal mean generation times were not significantly affected by the antibiotic treatments. Qualitative and quantitative changes in toxin production coincided with a reduction in the culturable, copiotrophic and/or intracellular bacteria in the A. minutum Anakoha A culture. The premise that bacteria can exert a strong influence on algal toxicity was supported by this study, although the mechanisms remain unknown.
\end{abstract}

KEY WORDS: Micro-algae $\cdot$ Paralytic shellfish toxins $\cdot$ Bacteria $\cdot$ Antibiotics $\cdot$ Alexandrium minutum • New Zealand

\section{INTRODUCTION}

Human paralytic shellfish poisoning (PSP), a potentially fatal condition, occurs through the ingestion of shellfish that have accumulated paralytic shellfish toxins (PST) produced by some species of dinoflagellates (Whittle \& Gallacher 2000, Taylor et al. 2003). Alexan- drium is one of several dinoflagellate genera that produce the PST saxitoxin (STX) and its derivatives. In 1994, a toxic bloom of A. minutum occurred in Anokoha Bay in the Marlborough Sounds of New Zealand. The bloom resulted in the closure of local shellfish beds and necessitated subsequent monitoring for PST contamination (MacKenzie 1994, MacKenzie \& 
Berkett 1997). In this case, the toxin profile of A. minutum closely resembled that of the collected shellfish (MacKenzie 1994, MacKenzie et al. 1994)

While the role of algal-associated bacteria in the production of PST is somewhat contentious, evidence is accumulating that suggests they may be capable of both autonomous PST production and PST metabolism (Ogata et al. 1990, Doucette 1995, Gallacher \& Smith 1999). One approach to defining the role of algalassociated bacteria is to create a bacteria-free (axenic) culture and assess the impact on PST production. Methods for obtaining axenic cultures have included growth on solid culture media (Guillard \& Keller 1984), antibiotic treatment, sometimes in combination with other antibacterial agents (Hunt \& Mandoli 1992, Cottrel \& Suttle 1993), and repeated washing of algal cells with or without the addition of antibiotics (Hoshaw \& Rosowski 1973, Uribe \& Espejo 2003). Although the antibiotic treatment method is potentially effective, difficulties are encountered because of the wide variety of bacterial species present, which are not necessarily amenable to removal by a single antibiotic. In addition, some antibiotics may have a deleterious effect on the algae (Divan \& Schnoes 1982). Proving the axenic status of an algal culture may be problematical because of the varying cultural requirements of the different bacterial species present and the fact that some may be non-culturable or intracellular (Gallacher \& Smith 1999, Lu et al. 2000).

As a first step toward understanding the role of bacteria associated with a PST-producing Alexandrium minutum strain isolated from Anakoha Bay, we aimed to develop an antibiotic treatment regimen, which effectively killed or inhibited the algalassociated bacteria. The effect of this regimen on PST production and algal growth was then determined. Toxin levels and profiles were assessed using a competitive enzyme-linked immunosorbent assay (ELISA) and high-performance liquid chromatography (HPLC), respectively, while algal mean generation times (MGTs) were determined by direct counting. In addition, intracellular bacteria were observed using laser scanning confocal microscopy following staining with acridine orange.

\section{MATERIALS AND METHODS}

The algal culture Alexandrium minutum Anakoha A (CAWD11) was obtained from L. MacKenzie, Cawthron Institute, Nelson, New Zealand (MacKenzie \& Berkett 1997). Algae were cultured in $300 \mathrm{ml}$ volumes of modified GP medium A in a Shearer Controlled Environment Chamber (Model CEL-37-14) under the following conditions: $20 \pm 2^{\circ} \mathrm{C}$, a $12: 12 \mathrm{~h}$ dark:light cycle and illumination of 80 to $100 \mu \mathrm{mol} \mathrm{m} \mathrm{m}^{-2} \mathrm{~s}^{-1}$ (Maas et al. 2000). The inoculum size used in every transfer was a $10 \%$ volume to volume transfer into fresh medium. Prior to transfer into the antibioticcontaining medium, the algal culture contained approximately 15000 cells $\mathrm{ml}^{-1}$ as determined by direct counting of aliquots fixed with Lugol's iodine using a Sedgewick-Rafter counting chamber (Graticules, SPI). Combinations of filter-sterilised penicillin G, streptomycin, kanamycin and tetracycline (Treatment 1); ciprofoxacin and gentamicin (Treatment 2); and penicillin, streptomycin and ciprofloxacin (Treatment 3) were added to the culture medium just prior to inoculation with the algae and again on Days 2 and 3 of the incubation period as shown in Table 1 (all antibiotics from Sigma, except for ciprofloxacin [Bayer NZ]). For Treatment 1, antibiotics were added to the experimental cultures (Transfer 0), which were incubated for $24 \mathrm{~h}$ before being transferred to fresh growth medium containing the same combination of antibiotics (Transfer 1). A further 3 transfers (Transfers 2 to 4 ) were made into medium containing antibiotic. Following Treatment 1, 8 algal transfers were made into antibiotic-free medium to allow residual bacterial populations to re-grow (Transfers 5 to 12). These cultures were then subjected to 2 further sequential treatments, which consisted of single transfers into medium containing different combinations of antibiotics (Transfers 13 and 14). Aliquots of the experimental and control algal cultures were taken at specific times for bacterial culture (either during transfers or during the incubation period) as shown in Table 1. The experiment was performed in duplicate, and control cultures had no antibiotics

Table 1. Timing of bacterial sampling and details of the antibiotic treatments used sequentially over 14 transfers during cultivation of Alexandrium minutum Anakoha A

\begin{tabular}{|c|c|c|}
\hline Transfers & $\begin{array}{l}\text { Antibiotics added to } \\
\text { algal growth medium } \\
\qquad\left(\mu \mathrm{g} \mathrm{ml}^{-1}\right)\end{array}$ & $\begin{array}{l}\text { Samples taken } \\
\text { for bacterial } \\
\text { culture at: }\end{array}$ \\
\hline $\begin{array}{l}\text { Treatment } 1 \\
0-4\end{array}$ & $\begin{array}{l}\text { Penicillin (50) } \\
\text { Streptomycin (50) } \\
\text { Kanamycin (30) } \\
\text { Tetracycline (5) }\end{array}$ & Transfer 4 \\
\hline $\begin{array}{l}\text { No Treatment } \\
5-12\end{array}$ & No antibiotics & Transfer 12 \\
\hline $\begin{array}{l}\text { Treatment } 2 \\
13\end{array}$ & $\begin{array}{l}\text { Ciprofloxacin (23) } \\
\text { Gentamicin (120) }\end{array}$ & $\begin{array}{l}\text { Day } 7 \text { after } \\
\text { Transfer } 13\end{array}$ \\
\hline $\begin{array}{l}\text { Treatment } 3 \\
14\end{array}$ & $\begin{array}{l}\text { Penicillin (100) } \\
\text { Streptomycin (100) } \\
\text { Ciprofloxacin (23) }\end{array}$ & $\begin{array}{c}\text { Days } 6,12 \text { and } 18 \\
\text { after Transfer } 14\end{array}$ \\
\hline
\end{tabular}


added. For all experimental and control algal cultures, transfers were carried out when the algae reached exponential growth phase as determined by direct counting of Lugol's iodine-fixed samples using a Sedgwick-Rafter counting chamber. This occurred between Days 15 and 20 of the incubation period. The effect of the antibiotic treatments on algal growth was investigated by comparing MGTs in the control and experimental cultures following the final transfer. Cell numbers were determined by direct count on Days 0 and 18.

Samples (1 ml) for bacterial culture (Table 1) were serially diluted 10-fold in sterile seawater and spreadplated in duplicate on marine agar ZoBell 2216 (MA; Difco), seawater complete agar (SWC; Haygood \& Nealson 1985) and GP medium B modified with $0.01 \%$ yeast extract (GPLY; Maas et al. 2000). MA was included to obtain an estimate of the copiotrophic bacteria, which require relatively high concentrations of nutrients, whereas the other media contained low concentrations of nutrients to support growth of oligotrophic bacteria. Plates were incubated at $25^{\circ} \mathrm{C}$ for $72 \mathrm{~h}$ and examined for colonies. Colony forming units (CFUs) $\mathrm{ml}^{-1}$ were converted to CFUs per 1000 algal cells to allow comparison between the different stages of treatment. Following the final transfer, the algal cultures were sampled for bacteria on Days 6,12 and 18 of the incubation period, and plates were incubated for $2 \mathrm{wk}$.

To assess the suitability of ciprofloxacin and gentamicin for the elimination of the residual bacterial population following Treatment 1, 14 randomly selected isolates were tested on GP medium B with $1 \%$ yeast extract for susceptibility using Epsilon-test strips (AB Biodisk) according to the manufacturer's instructions. Escherichia coli (ATCC 25922) was used as a sensitive control and tested on Mueller Hinton agar in parallel.

Prior to Treatment 1 and on Day 18 of Treatment 3, $10 \mathrm{ml}$ samples of algal cells were fixed overnight at $4^{\circ} \mathrm{C}$ in $30 \mathrm{ml}$ of $4 \%$ paraformaldehyde (Sigma) in phosphate buffered saline (PBS), centrifuged for $15 \mathrm{~min}$ $(500 \times g)$ and re-suspended in $100 \mu$ of 1:1 absolute ethanol (Ajax Finechem) PBS. The cells were placed on glass slides, gently heat fixed, treated with 50, 80 and $100 \%$ ethanol for 3 min each, stained with acridine orange (Sigma) and viewed using a laser scanning confocal microscope (Leica Microsystems).

Samples for toxin analysis were collected from the antibiotic-treated and control Alexandrium minutum cultures in mid-log phase following Transfers 4, 13 and 14 (Table 1). Samples for STX evaluation by ELISA (5 ml) were acidified with $1 \mathrm{M}$ acetic acid (final concentration of $0.1 \mathrm{M}$ ), sonicated for $3 \mathrm{~min}$ on ice (Sonicator $^{\mathrm{TM}}$ Cell Disruptor, Heat Systems-Ultrasonic) and stored at $-20^{\circ} \mathrm{C}$. Using antibodies provided by Prof. G. Terplan (Ludwig Maximilian University, Munich, Germany), immunological analysis was performed by direct competitive ELISA in triplicate (Usleber et al. 1991). Samples were diluted a minimum of $1 / 10$ with PBS to eliminate matrix interference. The majority of the samples required a dilution of between 1/25 and $1 / 1000$ to be within the linear portion of the standard curve. Media blanks and control cultures were included and results expressed as ng saxitoxin equivalents per 10000 algal cells. HPLC assays for STX, NeoSTX and gonyautoxins $\left(\mathrm{GTX}_{1-4}\right)$ were performed on samples acidified with $3 \mathrm{M}$ acetic acid (final concentration $0.3 \mathrm{M}$ ) and homogenised in $3 \times 30 \mathrm{~s}$ bursts on ice using a sonicator. The homogenate was filtered using an ultra-filtration kit (10 $000 \mathrm{kDa}$ cut-off; Millipore) as per the manufacturer's instructions. The filtrate was subjected to HPLC as described by Oshima et al. (1989) using the conditions of MacKenzie et al. (1996). The standards, containing certified levels of STX, NeoSTX and GTX $_{1-4}$, were obtained from the Institute of Marine Biosciences (Halifax, Nova Scotia, Canada).

ANOVA and Tukey post hoc tests were used to analyse algal MGTs, and bacterial counts were compared using a Student's $t$-test.

\section{RESULTS AND DISCUSSION}

Bacterial counts obtained from the antibiotic-treated and control (untreated) algal cultures sampled during the experiment are summarised in Table 2. The broad spectrum of activity provided by the initial round of antibiotic treatment (Treatment 1) significantly reduced the population growing on MA by $4 \times \log _{10}$ CFU ml ${ }^{-1}$ compared to the control $(p<0.001)$ but did not eliminate it. Possible reasons for this include innate or acquired antibiotic resistance among the survivors and/or the presence of stationary phase or dormant bacteria, which are more tolerant to antibiotics (Coates \& Hu 2006). Due to the presence of bacteria on the MA plates that were also able to grow on SWC and GPLY, oligotrophic counts for Transfer 4 could not be accurately determined. Transfers 5 to 12 were carried out in medium without antibiotics, and plate counts from Transfer 12 indicated that the residual bacterial population had increased to a level comparable to the control algal culture (Table 2). Antibiotic susceptibility testing of 14 isolates selected from this population indicated that the minimum inhibitory concentrations (MIC) were 0.016 to $12 \mu \mathrm{g} \mathrm{m}^{-1}$ for gentamicin and 0.002 to $2 \mu \mathrm{g} \mathrm{ml}^{-1}$ for ciprofloxacin in $11 / 14$ susceptible isolates. Two isolates were resistant to gentamicin (MIC $>256 \mu \mathrm{g} \mathrm{ml}^{-1}$ ) and a third to ciprofloxacin (MIC $>32 \mu \mathrm{g} \mathrm{ml}^{-1}$ ), indicating that resistance to these antibi- 
Table 2. Bacterial plate counts in $\mathrm{CFU} \mathrm{m}{ }^{-1}( \pm \mathrm{SE})$ obtained on the culture media marine agar (MA), seawater complete agar (SWC) and modified GP medium B (GPLY) from antibiotic-treated and untreated cultures of Alexandrium minutum Anakoha A. nd: not determined; -: no bacteria detected

\begin{tabular}{|lccc|}
\hline Algal culture transfer & MA & SWC & GPLY \\
\hline Control & & & \\
Transfer 4 & $5.6 \times 10^{6}$ & nd & nd \\
& $\left( \pm 1.1 \times 10^{4}\right)$ & & \\
Transfer 12 & $6.6 \times 10^{5}$ & $3.1 \times 10^{5}$ & $9.9 \times 10^{4}$ \\
& $\left( \pm 1.1 \times 10^{4}\right)$ & $\left( \pm 2.1 \times 10^{4}\right)$ & $\left( \pm 6.7 \times 10^{3}\right)$ \\
Day 7 following Transfer 13 & $1.0 \times 10^{6}$ & $1.1 \times 10^{6}$ & $2.3 \times 10^{5}$ \\
& $\left( \pm 1.3 \times 10^{5}\right)$ & $\left( \pm 9.6 \times 10^{4}\right)$ & $\left( \pm 8.4 \times 10^{4}\right)$ \\
& $4.1 \times 10^{5}$ & $3.02 \times 10^{5}$ & $4.0 \times 10^{5}$ \\
Day 18 following Transfer 14 & $\left( \pm 2.1 \times 10^{3}\right)$ & $\left( \pm 8.25 \times 10^{2}\right)$ & $\left( \pm 3.2 \times 10^{3}\right)$ \\
& & & \\
& & & $n$ \\
Antibiotic-treated & $6.7 \times 10^{2}$ & $\mathrm{nd}$ & \\
Transfer 4 (Treatment 1) & $\left( \pm 5.3 \times 10^{2}\right)$ & & $2.7 \times 10^{5}$ \\
& $5.2 \times 10^{5}$ & $3.9 \times 10^{5}$ & $\left.2.7 \times 10^{4}\right)$ \\
Transfer 12 (no antibiotics) & $\left( \pm 2.2 \times 10^{4}\right)$ & $\left( \pm 4.7 \times 10^{4}\right)$ & $\left( \pm 1.4 \times 10^{4}\right.$ \\
& $1.0 \times 10^{5}$ & $1.2 \times 10^{5}$ & $3.3 \times 10^{4}$ \\
Day 7 following Transfer 13 & $\left( \pm 1.6 \times 10^{4}\right)$ & $\left( \pm 4.7 \times 10^{3}\right)$ & $\left( \pm 2.9 \times 10^{3}\right)$ \\
(Treatment 2) & - & - & - \\
Day 18 following Transfer 14 & & & \\
(Treatment 3) & & & \\
\hline
\end{tabular}

tained following Treatment 1 (analysis following Treatment 2 was not performed). No unresolved peaks were seen in any of the HPLC traces. Overall, a decrease in toxin production, particularly STX, was associated with a decrease in the copiotrophic bacterial population in the antibiotic treated A. minutum cultures. As the fate of the non-culturable, dinoflagellate-associated bacteria was unknown, it is not possible to unequivocally link the copiotrophic population to toxin production. Lu et al. (2000) have suggested that heterotrophic bacteria are partly or wholly responsible for toxin production in dinoflagellate cultures. Heterotrophic bacteria are intimately associated with algae, which represent the primary source of organic nutrients (Doucette 1995). Thus, they would have the opportunity to both metabolise and produce PST (Gallacher \& Smith 1999). However, these authors have not dis-

otics occurs in bacteria of marine origin, as also noted by Hold et al. (2001). A second round of antibiotic treatment (Treatment 2) reduced the bacterial population (sampled on Day 7 ) by approximately $1 \times \log _{10}$, but a third treatment (Treatment 3) was required to diminish counts on all media to below detectable levels (i.e. $<10 \mathrm{CFU} \mathrm{ml} \mathrm{m}^{-1}$ ). Bacteria were detected at low levels (10 CFU per 1000 algal cells) on Days 6 and 12 of the incubation, but no colonies were recovered on Day 18. Over the 14 transfers, bacterial counts on MA and SWC in the algal control cultures were slightly, but not significantly, reduced. A number of other authors have reported the successful elimination of bacteria from dinoflagellate cultures using treatment regimens combining ciprofloxacin and gentamicin with other antibiotics (Lu et al. 2000, Hold et al. 2001, Ho et al. 2006).

The ELISA data indicated that STX levels were significantly lower $(p<0.001)$ in the cultures that received Treatment 1 compared to the untreated controls, but no significant changes were seen after Treatments 2 and 3 (Table 3). HPLC analysis showed that the toxin profile of the untreated Alexandrium minutum culture was $\mathrm{STX}^{+}$, Neo-STX ${ }^{-}, \mathrm{GTX}_{-1}{ }^{+}, \mathrm{GTX}-2^{+}, \mathrm{GTX}_{-} 3^{+}$and GTX $-4^{-}$. Following Treatment 1, STX was not detected, and the levels of GTX-1, GTX-2 and GTX-3 had decreased from $0.8,0.1$ and $0.6 \mu \mathrm{g}$ toxin derivatives per 10000 algal cells in the controls to $0.1,0.05$ and 0.1 in the antibiotic treated (Treatment 1) cultures, respectively. Samples taken on Day 18 following Treatment 3 were also subjected to HPLC, but the toxin profile showed no significant change compared to that ob- tinguished between copiotrophs, which require high nutrient concentrations, and oligotrophs, which are able to grow in low concentrations, within the bacterial population.

Several studies have sought to clarify the relationship between toxin production and algal-associated bacteria in the dinoflagellate genus Alexandrium (Lu et al. 2000, Hold et al. 2001, Uribe et al. 2003). However, it is difficult to compare studies because of variations in the treatment regimens used to render the algal cultures bacteria-free and the different methods used to assess the axenic status. In addition, changes in toxin levels may be associated with a reduction or increase in algal growth, but this has not always been measured (see comment in Gallacher \& Smith 1999). In the present study, algal MGTs were slightly longer for the antibiotic-treated culture compared to the control following the final transfer (average of 4.93 and

Table 3. Saxitoxin production in cultures of Alexandrium minutum Anakoha A receiving 3 sequential antibiotic treatments as measured by ELISA. Values are saxitoxin equivalents in ng per 10000 algal cells $( \pm$ SE)

\begin{tabular}{|lrc|}
\hline $\begin{array}{l}\text { Antibiotic } \\
\text { treatment }\end{array}$ & $\begin{array}{c}\text { Total toxin } \\
\text { content }\end{array}$ & $\begin{array}{c}\text { Total toxicity } \\
(\%)\end{array}$ \\
\hline $\begin{array}{l}\text { Original algal culture } \\
\text { Treatment 1 }\end{array}$ & $\begin{array}{c}92.3( \pm 10.8) \\
\text { Treatment 2 }\end{array}$ & 100 \\
Treatment 3 & $20.6( \pm 1.66)$ & 33.09 \\
& $12.67( \pm 1.42)$ & 20.96 \\
\hline
\end{tabular}


$5.47 \mathrm{~d}$, respectively). However, this difference was not significant, indicating that algal growth was not significantly affected by either elimination of the associated bacteria or the antibiotic treatment regimen. Both increases and decreases in PST production have been previously reported following elimination of the bacterial population from dinoflagellate cultures (Lu et al. 2000, Hold et al. 2001, Uribe \& Espejo 2003, Ho et al. 2006). Because of the possible presence of non-culturable bacteria, only the DNA-based studies of Hold et al. (2001) and Uribe \& Espejo (2003) can be considered to include true axenic cultures. Nevertheless, both increases and decreases in toxicity were recorded following removal of the bacterial population. As Hold et al. (2001) pointed out, changes in many parameters influence dinoflagellate growth and toxin production, and it may be that a further parameter is the associated bacteria, which exert their effect through a number of mechanisms (Gallacher \& Smith 1999).

A number of studies have addressed the question of intracellular bacteria and their role in toxin production (Kodama 1990, Ogata et al. 1990, Lu et al. 2000, Biegala et al. 2002). In Alexandrium, these probably arise from dinoflagellates preying on bacterivorous organisms rather than direct phagocytosis (Gallacher \& Smith 1999). Again, conflicting results have been obtained, and the true picture may be obscured by differences in methods. Biegala et al. (2002) used fluorescent in situ hybridisation (FISH) to detect intracellular bacteria in $A$. tamarense and $A$. fundyense. Despite the apparent absence of intracellular bacteria by FISH, bacteria-like particles (BLP) were seen in transmission electron micrographs. In the present study, intracellular BLP (approximately $1 \mu \mathrm{m}$ in size) were detected in A. minutum Anakoha A by laser scanning confocal microscopy following staining with acridine orange, a DNA/RNA stain. BLP were numerous prior to the antibiotic treatments but considerably reduced following the final transfer (Fig. 1). Two of the antibiotics (tetracycline and ciprofloxacin) are used to treat intracellular infections (Greenwood 1995a,b), and it seems likely that they were able to penetrate the algal cells inhibiting the intracellular bacteria.

The present study is the first to link the presence of culturable, copiotrophic and/or intracellular bacteria with PST production in an algal culture. On the other hand, there was no such link between toxicity and the culturable oligotrophic population associated with Alexandrium minutum Anakoha A. In New Zealand and elsewhere, identification of algal species is the sole criterion for predicting whether a bloom is toxic or not. However, this may be a blunt tool given the accumulating evidence that bacteria exert a strong influence on algal toxicity.
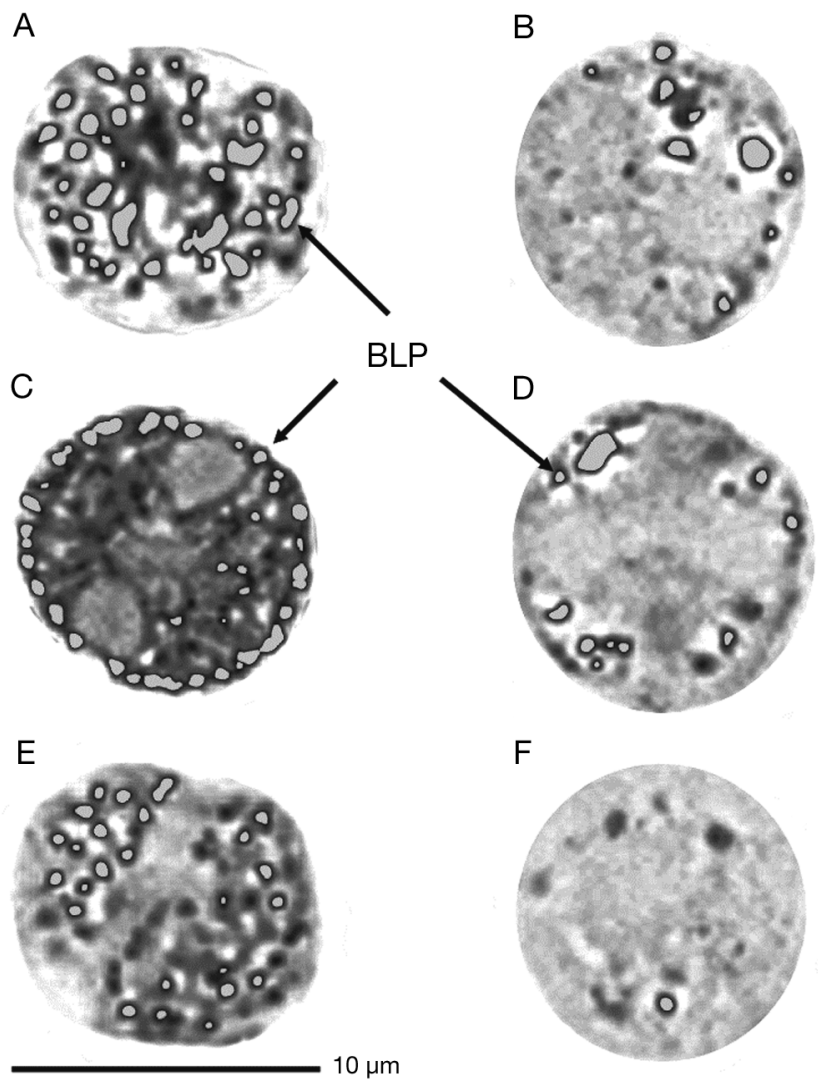

BLP
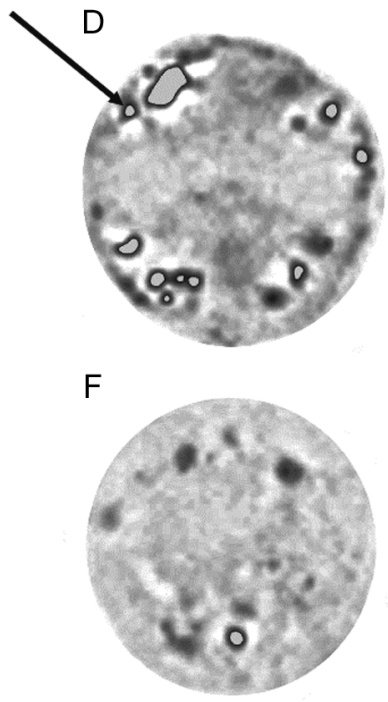

Fig. 1. Alexandrium minutum. Representative cells stained with acridine orange, captured with a laser scanning confocal microscope, showing the localisation and distribution of bacteria-like particles (BLP). ( $\mathrm{A}, \mathrm{C}, \mathrm{E})$ An algal cell prior to antibiotic treatment; $(\mathrm{B}, \mathrm{D}, \mathrm{F})$ an algal cell after 3 antibiotic treatments (Transfer 14). $(\mathrm{A}, \mathrm{B}),(\mathrm{C}, \mathrm{D})$ and $(\mathrm{E}, \mathrm{F})$ respectively show sections through the top, middle and bottom of the algal cell

Acknowledgements. We thank L. MacKenzie, Cawthron Institute, Nelson, New Zealand, for the continued use of his Alexandrium minutum Anakoha A isolate. E.W.M. was funded by a Health Research Council of New Zealand postgraduate scholarship. We thank Dr. I. Garthwaite, AgResearch, Hamilton, New Zealand, for the ELISA analysis and the Cawthron Institute for the use of their HPLC and toxin standards. A.M.W. was supported by a Postdoctoral fellowship from the Victoria University of Wellington. All confocal microscopy herein was completed using a Leica confocal microscope administered by the School of Biological Sciences, Victoria University of Wellington. We thank G. Rickards for extensive training and assistance with the confocal work.

\section{LITERATURE CITED}

Biegala IC, Kennaway G, Alverca E, Lennon JF, Vaulot D, Simon N (2002) Identification of bacteria associated with dinoflagellates (Dinophyceae) Alexandrium spp. using tyramide signal amplification-fluorescent in situ hybridization and confocal microscopy. J Phycol 404-411 
Coates AR, Hu Y (2006) New strategies for antibacterial drug design: targeting non-multiplying latent bacteria. Drugs $\mathrm{R}$ D 7:133-151

Cottrell MT, Suttle CA (1993) Production of axenic cultures of Micromonas pusilla (Prasinophyceae) using antibiotics. J Phycol 29:385-387

Divan CL, Schnoes HK (1982) Production of axenic Gonyaulax cultures by treatment with antibiotics. Appl Environ Microbiol 44:250-254

Doucette GJ (1995) Interactions between bacteria and harmful algae: a review. Nat Toxins 3:65-74

Gallacher S, Smith EA (1999) Bacteria and paralytic shellfish toxins. Protist 150:245-255

Greenwood D (1995a) Inhibitors of protein synthesis. In: Greenwood D (ed) Antimicrobial and chemotherapy. Oxford University Press, Oxford, p 32-48

Greenwood D (1995b) Synthetic antibacterial agents and miscellaneous antibiotics. In: Greenwood D (ed) Antimicrobial and chemotherapy. Oxford University Press, Oxford, p 49-61

Guillard RRL, Keller MD (1984) Culturing dinoflagellates. In: Spector DL (ed) Dinoflagellates. Academic Press, Burlington, MA, p 391-442

Haygood MG, Nealson KH (1985) Mechanisms of iron regulation of luminescence in Vibrio fischeri. J Bacteriol 162: 209-216

Ho AYT, Hsieh DPH, Qian PY (2006) Variations in paralytic shellfish toxin and homolog production in two strains of Alexandrium tamarense after antibiotic treatments. Aquat Microb Ecol 42:41-53

Hold GL, Smith EA, Birkbeck TH, Gallacher S (2001) Comparison of paralytic shellfish toxin (PST) production by the dinoflagellates Alexandrium lusitanicum NEPCC 253 and Alexandrium tamarense NEPC 407 in the presence and absence of bacteria. FEMS Microbiol Ecol 36:223-234

Hoshaw RW, Rosowski JR (1973) Methods for microscopic algae. In: Stein JR (ed) Handbook of phycological methods: culture methods and growth measurements. Cambridge University Press, Cambridge, p 53-67

Hunt BE, Mandoli DF (1992) Axenic cultures of Acetabularia (Chlorophyta): a decontamination protocol with potential application to other algae. J Phycol 28:407-414

Kodama M (1990) Possible links between bacteria and toxin production in algal blooms. In: Granéli E, Sundström B, Edler L, Anderson DM (eds) Toxic marine phytoplankton: Proc 4th Int Conf Toxic Mar Phytoplankton. Elsevier, New

Editorial responsibility: Edna Granéli,

Kalmar, Sweden
York, p 52-62

Lu YH, Chai TJ, Hwang DF (2000) Isolation of bacteria from dinoflagellate Alexandrium minutum and their effects on algae toxicity. J Nat Toxins 9:409-417

Maas EW, Thiele J, Thompson C, Latter RM, Brooks HJL (2000) Modification of an algal culture medium for sustained growth of a saxitoxin-producing isolate of Alexandrium minutum. J Appl Phycol 12:95-98

MacKenzie L (1994) More blooming problems: toxic algae and shellfish biotoxins in the South Island (January to May 1994). Seafood NZ 2:47-52

MacKenzie L, Berkett N (1997) Cell morphology and PSPtoxin profiles of Alexandrium minutum in the Marlborough Sounds, New Zealand. NZ J Mar Freshw Res 31: 403-409

MacKenzie L, White D, Rhodes L, Berkett N, Burke B, Haywood A (1994) Alexandrium and PSP in New Zealand - another chapter in the marine biotoxin saga. Seafood NZ 2:72-75

MacKenzie L, White D, Oshima Y, Kapa J (1996) The resting cysts and toxicity of Alexandrium ostenfeldii (Dinophycceae) in New Zealand. Phycologia 35:148-155

Ogata T, Kodama M, Komaru K, Sakomoto S, Sato S, Simidu U (1990) Production of paralytic shellfish toxins by bacteria isolated from toxic dinoflagellates. In: Granéli E, Sundström B, Edler L, Anderson DM (eds) Toxic marine phytoplankton: Proc 4th Int Conf Toxic Mar Phytoplankton. Elsevier, New York, p 311-315

Oshima Y, Sugino K, Yasumoto T (1989) Latest advances in HPLC analysis of paralytic shellfish. In: Natori $\mathrm{S}$, Hashimoto K, Ueno Y (eds) Mycotoxins and Phycotoxins '88. A collection of papers presented at the 7th international IUPAC symposium on mycotoxins and phycotoxins. Elsevier, New York, p 319-326

Taylor FJR, Fukuyo Y, Larsen J, Hallegraeff GM (2003) Taxonomy of harmful dinoflagellates. In: Hallegraeff GM, Anderson DM, Cembella AD (eds) Manual on harmful marine microalgae. UNESCO, Paris, p 389-432

Uribe P, Espejo RT (2003) Effect of associated bacteria on the growth and toxicity of Alexandrium catenella. Appl Environ Microbiol 69:659-662

Usleber E, Schneider E, Terplan G (1991) Direct enzyme immunoassay in microtitration plate and test strip format for detection of saxitoxin in shellfish. Lett Appl Microbiol 13:275-277

Whittle K, Gallacher S (2000) Marine toxins. Br Med Bull 56: $236-253$

Submitted: November 15, 2006; Accepted: May 16, 2007

Proofs received from author(s): July 18, 2007 